\title{
Legal Protection of Patient Data Confidentiality Electronic Medical Records
}

(Perlindungan Hukum Kerahasiaan Data Pasien dalam Rekam Medik Elektronik)

\author{
Nabbilah Amir \\ email: nabila.amir@staff.ubaya.ac.id \\ Faculty of Law, University of Surabaya, Surabaya
}

\begin{abstract}
The use of electronic devices is inseparable from life today, entering the Industrial Revolution era where technological sophistication can replace human tasks, so the use of electronic devices can not only be found in domestic life, offices, and education but also in medical services. The various facilities offered by health care providers both hospitals and clinics in the form of technology utilization are increasingly rapidly becoming one of the electronic medical records that are expected to have a positive impact on reducing paper use. Medical records that used paper (conventional) were changed to electronic medical records. The purpose of this study is to find out and analyze the extent to which electronic medical records can protect the confidentiality of patient data and function as evidence in court in malpractice cases. This study uses normative legal research methods and uses the statute approach method. The results of this study indicate that there needs to be a concern from the government in providing legal certainty regarding the existence of electronic medical records, given that the application has been carried out by several hospitals and clinics in Indonesia. The government should provide standard legal certainty to the changes in conventional medical records to electronic medical records in the form of the issuance of specific laws and regulations regulating electronic medical records.
\end{abstract}

Keywords: legal protection; electronic medical records

\section{PENDAHULUAN}

Perkembangan ilmu pengetahuan dewasa ini telah merubah dunia, dimana dalam perkembangan zaman berbagai hal telah digantikan oleh kecanggihan teknologi. Tahap pemanfaatan dalam berbagai aspek bukan hanya manusia yang saat ini mulai tergantikan dengan robot, tetapi juga beberapa system menejemen salah satunya system menejemen kesehatan. Dimulai dari pemberlakuan pendaftaran ke rumah sakit yang sudah menggunakan system online sampai dengan rekam medis yang turut beralih ke elektronik. Rekam medis yang semula secara proses pelayanan medis dengan cara yang konvensional yakni menggunakan kertas dan memerlukan jasa manusia dalam penyimpanan dan pencarian berubah menjadi elektronik yakni menggunakan system teknologi informasi berdasarkan kebutuhan klinik atau rumah sakit.

Penerapan rekam medis elektronik kemudian menjadi trend di Indonesia mengingat penerapan rekam medis eletronik ini merupakan salah satu upaya dalam peningkatan kualitas pelayanan kesehatan, peningkatan efisiensi biaya, daya dukung para tenaga medis dan memiliki peran penting dalam keamanan pelayanan medis terhadap pasien. Bukan itu saja, rekam medis elektronik ini juga diharapkan dapat mengurangi kesalahan klinis dan mengurangi kesalahan dalam pengarsipan. Serta, jika dipahami lebih lanjut, salah satu hal 
yang menyebabkan rekap medis elektronik menjadi booming yakni kemudahan akses antara, rumah sakit, pihak administrasi dan dokter, bahkan depo kefarmasian (apoteker) untuk pemberian resep obat dalam melihat riwayat kesehatan pasien. Hal ini senada dengan pendapat $M$ Yusuf Hanfiah dan Amri Amir menyatakan bahwa "peranan rekam medis sangat penting dan melekat erat dengan kegiatan pelayanan kedokteran maupun pelayanan kesehatan". ${ }^{1}$

Rekam medik atau rekam medis/kesehatan adalah rekam dalam bentuk tulisan atau gambaran aktivitas pelayanan yang diberikan oleh pemberi pelayanan medis/kesehatan kepada seorang pasien. ${ }^{2}$ Sehingga dalam hal ini dapat diartikan bahwa rekam medis merupakan kewajiban dalam hal pelayanan medis baik itu di klinik maupun dirumah sakit.

Pengaturan tentang rekam medis secara ekplisit telah diatur oleh pemerintah Indonesia melalui Departemen Kesehatan yang telah mengeluarkan Peraturan Menteri Kesehatan Nomor 749a/MENKES/ Per/XII/1989 Tentang Rekam Medik/ Medical Records. Dan kemudian timbulnya kesadaran pemerintah terhadap perkembangan kecanggihan teknologi sehingga diterbitkan Peraturan Menteri Kesehatan No. 269 Tahun 2008 Tentang Rekam Medik, yang menjelaskan bahwa" Rekam Medik harus dibuat secara tertulis, lengkap, dan jelas atau secara elektronik.

Selanjutnya, dalam pelayanan kesehatan dapat ditemukan pula pengaturan terkait rekam medis yang menjelaskan bahwa membuat Rekam medis merupakan salah satu kewajiban dokter yang tercantum didalam Serta di dalam Undang-undang No.29 Tahun 2004 tentang Praktik Kedokteran yakni didalam pasal 46 ayat (1) sampai dengan ayat (3) dan pasal 47 ayat (1) sampai dengan ayat (3) apabila kewajiban ini dilanggar, dokter akan terkena sanksi pidana berdasar ketentuan didalam pasal 79 huruf b UU Praktik Kedokteran tersebut.

Pencatatan rekam medik kemudian menjadi wajib, mengingat isi didalam rekam medik adalah data sosial, data demografi kesehatan dan hasil diagnosis dokter pasca pemeriksaan dan keluhan yang dihadapi oleh pasien. Sehingga keakuratan, ketelitian dan kerahasiaan menjadi dasar dalam penyimpanan data pasien tersebut mengingat tanggung jawab terhadap rekam medik sangat besar. Ketika kemudian rekam medik konvensional berubah menjadi rekam medik elektronik menimbulkan berbagai pro dan kontra. Tidak sedikit para ahli mengkhawatirkan akan terbukanya rahasia pasien karena system elektronik yang menggunakan kecanggihan tekhnologi informasi tingkat keamanan belum dapat di jamin aman.

Sesuai dengan program yang direncanakan oleh pemerintah berlandaskan pada dasar Pembangunan Kesehatan, dan untuk mewujudkan Visi Indonesia Sehat 2025, ditetapkan misi Pembangunan Kesehatan, yaitu meningkatkan dan mendayagunakan Sumber daya kesehatan yang meliputi sumber daya manusia kesehatan, pembiayaan kesehatan, serta sediaan farmasi dan alat kesehatan. Sumber daya kesehatan meliputi pula penguasaan ilmu pengetahuan dan teknologi kesehatan/kedokteran, serta data dan informasi yang makin penting peranannya. Salah satu data dan informasi (teknologi informasi) tentang kesehatan yang sesuai dengan arus globalisasi adalah Rekam Medis Elektronik. ${ }^{3}$

\footnotetext{
${ }^{1}$ M Yusuf Hanafiah \& Amri Amir, Etika Kedokteran dan Hukum Kesehatan, Buku Kedokteran EGC, 1999, Jakarta. Halaman 55.

${ }^{2}$ SK PB IDI No.315/PB/A.4/88 angka 1 (Didalam SK ini terdapat penjelasan runtut tentang Rekam Medik yang menjadi pedoman dokter, klinik dan rumah sakit dalam pelayanan kesehatan)

${ }^{3}$ Sudjana, Aspek Hukum Rekam Medis atau Rekam Medik Elektronik Sebagai alat bukti dalam transaksi terapeutik, VEJ Volume 3 Nomor 2, 2017, Bandung. Halaman 359.
} 
Mencermati Indonesia tersebut, maka tidak heran ketika beberapa klinik dan rumah sakit telah menerapkan system rekam medik elektronik. Namun, yang menjadi perhatian ketika rekam medik eletronik telah diterapkan sedangkan regulasi yang memberikan perlidungan hukum bagi kerahasiaan data pasien belum mendapatkan pengaturan yang jelas.

Berdasarkan uraian diatas maka dapat ditarik rumusan masalah sebagai berikut:

Apa yang menjadi dasar pentingnya regulasi spesifik terhadap pemberlakuan rekam medik elektronik sebagai upaya perlindungan kerahasiaan data pasien?

\section{METODE PENELITIAN}

Metode Penelitian yang digunakan dalam penelitian ini adalah Yuridis Normatif, yaitu penelitian yang difokuskan untuk mengkaji penerapan kaidah-kaidah atau norma-norma hukum positif. ${ }^{4}$ Selanjutnya penelitian ini menggunakan pendekatan perundang-undangan (Statute Aproach). Pendekatan perundang-undangan digunakan untuk mengetahui keseluruhan peraturan hokum positif di Indonesia. Pendekatan kasus digunkana untuk mengkaji penerapan norma-norma kaidah-kaidah hukum yang dilakukan dalam praktek penerapan rekam medik elektronik di Indonesia.

\section{PEMBAHASAN}

Rekam medik merupakan catatan yang dibuat oleh dokter yang berisi, data pasien, keluhan yang dirasakan pasien, pemeriksaan pasien, diagnosa dokter, tindakan yang dilakukan dokter dan memberikan obat-obatan kepada pasien yang kemudian disimpan atau diarsipkan oleh rumah sakit sehingga kerahasiaan data pasien mendapat jaminan dari Rumah sakit.

Dalam pelayanan kesehatan, pasien merupakan pihak yang menggunakan jasa para pelayan kesehatan yakni, dokter, perawat dan yang bernaung didalam klinik maupun rumah sakit. Pasien adalah subjek hukum yang mandiri, dimana pasien diberikan hak untuk mengambil keputusan untuk kepentingannya. Pada Pasal 1 Angka 10 UU No. 29 Tahun 2004 menyatakan bahwa pasien adalah setiap orang yang melakukan konsultasi masalah kesehatannya untuk memperoleh pelayanan kesehatan yang diperlukan baik secara langsung maupun tidak langsung kepada dokter atau dokter gigi.

Pasien merupakan subjek hukum mandiri yang dianggap dapat mengambil keputusan untuk kepentingan dirinya, dan secara relatif pasien berada dalam posisi yang lebih lemah untuk membela kepentingannya dalam situasi pelayanan kesehatan. Ini sering kali menimbulkan adanya keinginan/kebutuhan untuk mempermasalahkan hak-hak pasien dalam menghadapi tenaga kesehatan khususnya dokter. ${ }^{5}$

Selanjutnya menurut Soerjono Soekanto mendifinisikan bahwa pasien adalah subjek hukum mandiri yang diangap dapat mengambil keputusan untuk kepentingannya sendiri. ${ }^{6}$

Rekam medik merupakan sebuah catatan rahasia milik pasien yang dilakukan oleh dokter dalam hubungan transaksi terapeutik antara dokter dan pasien baik yang diungkapkan secara langsung oleh pasien maupun yang diketahui oleh dokter ketika

\footnotetext{
4 Johny Ibrahim, Teori dan Metodologi Penelitian Hukum Normatif, Bayu Media Publishing, 2006, Malang. Halaman 295.

5 Zaeni Asyhadie, Aspek-Aspek Hukum Kesehatan Di Indonesia, Rajawali Pers, 2017, Depok. Halaman 70-71.

6 Soerjono Soekanto,Segi-segi hukum hak dan kewajiban pasien dalam kerangka hukum kesehatan, Mandar Maju, 1990, Bandung. Halaman 27.
} 
melakukan pemeriksaan fisik dan penunjang. Selain dari itu, rekam medis bersifat rahasia yang sering kali disebut dengan rahasia medik atau disebut dengan rahasia jabatan dokter yang timbul karena menjalankan tugas profesionalnya sebagai dokter.

Kerahasiaan rekam medik sudah seharusnya sesuai dengan aturan perundang-undangan yakni dilakukan penyimpanan dan dijaga kerahasiaannya karena data yang terdapat dalam rekam medik adalah milik pasien, kewajiban ini menjadi tugas dokter atau dokter gigi dan pemimpin sarana pelayanan kesehatan dalam hal ini yang dimaksud adalah rumah sakit/klinik. Seiring berkembangnya zaman, ditambah lagi dengan dicanangkannya Revolusi Industri 4.0 yang menjadikan system informasi dan telekomunikasi semakin berkambang dan diterapkan dalam kehidupan sehari-hari bukan hanya pada sektor perkantoran dan rumah sakit, hal ini juga mempengaruhi system pelayanan didalam dunia kesehatan (dalam hal ini adalah Rumah sakit atau klinik) perkembangan system informasi berkembang hingga dalam pemanfaatan pencatatan rekam medik yakni rekam medik elektronik.

Keberadaan rekam medik elektronik ini kemudian menimbulkan pro dan kontra dalam menghadapi sebuah penemuan baru dalam penerapan sistem menejemen pelayanan kesehatan. Secara positif keberadaan rekam medik ini merupakan teknologi terbarukan dalam mengurangi penggunaan kertas dalam penyimpanan data pasien, seperti yang diketahui bahwa pembuatan kertas menggunakan bahan kayu yang kemudian diolah menjadi kertas dengan menggunakan berbagai bahan kimia sehingga dapat digunakan sebagai alat tulis. Maka keberadaan rekam medik elektronik ini kemudian menjadi sebuah trobosan dalam pengurangan penggunaan kertas yang berarti juga meminimalisir penebangan kayu. Yang berarti turut dalam menjaga kelangsungan lingkungan hidup.

Beranjak dari penggunaan non kertas pada rekam medik atau rekam medik elektronik yang melahirkan paradigma baru dalam sistem manajemen kesehatan, menjadi sebuah sistem terintergrasi dalam pemanfaatan diklinik maupun rumah sakit hal ini sebagaimana diatur didalam Peraturan Menteri Kesehatan No. 269/MENKES/PER/III/2008 pasal 2 yang berisi “(1) Rekam Medis harus dibuat secara tertulis, lengkap dan jelas atau secara elektronik; (2) Penggunaan teknologi informasi elektronik diatur lebih lanjut dengan peraturan tersendiri.

Manfaat Rekam Medis Elektronik (RME) memudahkan pekerjaan dokter dan kebutuhan pasien dalam mendapatkan layanan medis. Hal ini meliputi kemudahan yang ditawarkan dalam sistem sejarah rekam medis pasien, identifikasi dan penanggulangan penyakit, manajemen jadwal kunjungan pasien, serta observasi indikator kesehatan pasien. Adapun manfaat dari pelaksanaan rekam medik elektronik yang lainnya adalah:

1. Penelusuran dan pengiriman informasi mudah;

2. Bisa dikaitkan dengan informasi diluar rumah sakit;

3. Penyimpanan lebih ringkas, data dapat ditampilkan dengan cepat sesuai kebutuhan;

4. Pelaporan lebih mudah dan secara otomatis;

5. Kualitas data dan standar dapat dikendalikan;

6. Dapat diintegrasikan dengan perangkat lunak pendukung keputusan;

7. Lebih cepat dan efisien dalam memberikan pelayanan kepada pasien;

8. Tidak membutuhkan kertas, sehingga dapat menghemat penggunaan kertas;

9. Dapat melakukan copy cadangan informasi yang dapat diambil apabila terjadi kehilangan data yang asli;

10. Dapat memproses data yang banyak dalam waktu yang singkat;

11. Dapat mengurangi medical error. 
Dewasa ini, pemanfaatan rekam medik elektronik masih mengikuti sistem rekam medik konvensional, namun secara perlindungan hukum menjadi menarik ketika penerapan telah dilakukan tetapi regulasinya masih abstrak. Menurut Fred Ameln, Ada dua fungsi hukum yang menonjol yaitu:

1. Kepastian Hukum;

2. Perlindungan Hukum. ${ }^{7}$

Kedua fungsi hukum tersebut memang tidak ditujukan pada aspek tertentu sehingga penerapannya dapat diberlakukan pada seluruh aspek hukum termaksud hukum kesehatan.

Lebih lanjut, menurut Fred Ameln, dalam pelayanan kesehatan/Health Care, terdapat dua kelompok yang perlu dibedakan, yaitu:

1. Health Receivers, yaitu penerima pelayanan kesehatan. Yang termaksud didalam kelompok ini:

- Pasien, yaitu orang yang sakit;

- Mereka yang ingin memelihara/meningkatkan kesehatannya, misalnya ingin divaksinasi atau wanita hamil yang memeriksakan kandungannya.

2. Health Providers, yaitu pemberi pelayanan kesehatan. Contohnya:

- Medical Providers: dr, drg.

- Tenaga bidang kesehatan lain: apoteker; asisten apoteker, bidan, perawat, analis/laboran, ahli gizi, dan lain-lain.

- Kedua kelompok tersebut menginginkan adanya kepastian dan perlindungan secara hukum. ${ }^{8}$

Dokter, rumah sakit dan pasien adalah tiga subyek yang terkait dalam sistem pemeliharaan dan pelayanan kesehatan untuk mewujudkan kesehatan yang optimal. Ketiganya membentuk baik hubungan medik maupun hubungan hukum. Hubungan medik dan hubungan hukum antara dokter, rumah sakit dan pasien adalah hubungan yang obyeknya berupa pemeliharaan kesehatan pada umumnya dan pelayanan kesehatan pada khususnya. ${ }^{9}$

Kepastian hukum merupakan hal penting yang perlu diperhatikan didalam hukum kesehatan, dalam mewujudkan perlindungan hukum yang diberikan oleh standar pelayanan kedokteran adalah memberikan jaminan untuk bebas dari tuntutan malpraktek medis, meskipun dalam tindakan medis yang dilakukan oleh dokter terdapat kerugian pasien. Namun, dengan adanya ketidaklengkapan peraturan perundang-undangan yang disebab oleh tidak disahkannya pedoman nasional pelayanan kedokteran, maka tolak ukur kelalaian seorang dokter dalam menjalankan tindakan semakin samar. ${ }^{10}$

Ketidak lengkapan peraturan perundang-undangan ini juga berdampak pada pembaharuan terhadap rekam medik elektronik. Yang semula rekam medik konvensional dapat dijadikan menjadi salah satu alat bukti bagi dokter dan rumah sakit dalam tuduhan malpraktek yang dihadapi oleh dokter dan rumah sakit atau klinik. Keabsahan pencatatan rekam medik konvensional oleh dokter dapat dilihat melalui tanda tangan atau paraf dokter yang bersangkutan. Sedangkan apabila rekam medik berubah ke elektronik, bentuk keabsahaan

\footnotetext{
${ }^{7}$ Fred Ameln, Kapita Selekta Hukum Kedokteran, Grafikatama jaya, 1991, Jakarta. Halaman 13.

${ }^{8}$ Ibid

${ }^{9}$ Wila Chandrawila Supriadi, Hukum Kedokteran, Mandar Maju, 2001, Jakarta. Halaman 1.

${ }^{10}$ Bagus Tri Adikarya, Artikel Ilmiah Perlindungan Hukum Bagi Dokter Melalui Reformasi Standar Pelayanan Kedokteran Berdasarkan Prinsip Kepastian Hukum, Universitas Brawijaya, 2015, Malang. Halaman 2.
} 
rekam medik dibuat berdasarkan keterampilan yang dimiliki oleh bagian IT dan ketersediaan alat eletronik yang menunjang tersedianya rekam medik di rumah sakit atau klinik. Ada yang menggunakan PIN atau password dalam pengabsahan rekam medik elektronik tersebut, namun ada juga yang menggunakan fingerprint apabila bentuk alat eletronik yang dipakai adalah bentuk touch screen dan dapat menyimpan fingerprint. Atau bahkan ada yang menggunakan pola iris mata dalam pengenalan identitas dokter yang melakukan pencatatan dengan tujuan penguatan terhadap keabsahan rekam medik elektronik tersebut.

Data rekam medik elektronik ini juga dapat dikategorikan dalam pengaksesannya dalam artian petugas rumah sakit hanya diberikan akses tertentu dalam penggunaannya. Dikecualikan kepada dokter supervisor atau Dokter senior yang bertanggung jawab dalam melakukan pemeriksaan dan verifikasi terhadap hasil pemeriksaan yang dilakukan oleh dokter yang bersangkutan.

Saat ini kepastian hukum rekam medis elektronik memang belum mendapatkan fokus dari pemerintah meskipun upaya-upaya secara akademik dengan melakukan seminar dan diskusi telah dilakukan. Adapun kemudian permasalahan timbul akibat dari pemanfaatan rekam medik elektronik maka satu-satunya undang-undang yang dapat dirujuk yakni Undangundang tentang Informasi dan Transaksi Elektronik (UU ITE) No. 11 Tahun 2008.

Mencermati permasalahan yang sering timbul didalam dunia kesehatan tidak lepas dari malpraktek medis. Baik dokter maupun rumah sakit ataupun klinik dalam melakukan pembelaan terhadap standar operasional yang telah ditetapkan dalam kode etik kedokteran biasanya menggunakan rekam medik sebagai alat bukti hukum dalam proses penegakan hukum, disiplin kedokteran dan kedokteran gigi serta penegakan etika kedokteran dan etika kedokteran gigi. Rekam medik sebagai alat bukti ditegaskan didalam Pasal 13 ayat (1) huruf c Peraturan Menteri Kesehatan No. 269/MENKES/PER/III/2008 tentang Rekam Medis yang menyatakan:

"Pemanfaatan Rekam medis dapat dipakai sebagai alat bukti dalam proses penegakan hukum, disiplin kedokteran dan kedokteran gigi dan penegakan etika kedokteran dan kedokteran gigi."

Adapun yang dimaksud dengan rekam medik sebagai salah satu alat bukti, terlebih dahulu dapat dilihat penjelasan Pasal 184 ayat (1) Kitab UndangUndang Hukum Acara Pidana (KUHAP) disebutkan bahwa alat bukti yang sah adalah:

1. Keterangan Saksi;

2. Keterangan Ahli;

3. Surat;

4. Petunjuk;

5. Keterangan Terdakwa.

Rekam medik umumnya dapat dijadikan salah satu alat bukti yang berbentuk surat. Meskipun rekam medik tidak lantas menjadi alat bukti utama dalam kasus malpraktek namun cukup memberikan gambaran terhadap diagnosa, tindakan dan pemberian obatobatan yang diberikan dokter kepada pasiennya. 
Dalam bidang hukum, menurut Soerjono Soekanto rekam medik tersebut mempunyai fungsi utama sebagai ${ }^{11}$ :

1. Bahan pembuktian di sidang peradilan.

2. Sarana mengembalikan ingatan para pihak yang berpekara.

Selanjutnya Soerjono Soekanto menyatakan betapa pentingnya fungsi rekam medis ini bagi dokter dari aspek hukum, sebagaimana dikatakan sebagai berikut ${ }^{12}$ :

"Di dalam proses hukum, tidak adanya rekam kesehatan akan senantiasa menyudutkan atau merugikan tenaga kesehatan (dokter) dan rumah sakit. Hal ini disebabkan karena apabila tidak ada catatan di dalam rekam kesehatan, maka dianggap bahwa tidak ada bukti dilakukannya suatu pelayanan kesehatan tersebut".

Senada dengan hal tersebut, Syahrul Mahmud menegaskan "Tidak jarang suatu gugatan atau tuntutan pidana diajukan setelah beberapa tahun setelah terjadinya ada dugaan medical malpractice, oleh karena itu rekam medis ini sangat penting sekali peranananya dalam pembuktian benarkah ada medical malpractice."13

Sebagaimana yang telah dijelaskan sebelumnya bahwa salah satu petunjuk keabsahaan rekam medik untuk menjadi alat bukti yakni tanda tangan yang dibubuhkan oleh dokter. Perbedaan mendasar ketika rekam medik konvesional berubah menjadi rekam medik elektronik, bentuk keabsahan tersebut bukan lagi menggunakan tanda tangan umum namun menggunakan PIN atau Password sebagai identitas dokter yang berfungsi sebagai tanda tangan elektronik.

PIN atau Password dalam rekam medik berfungsi sebagai tanda tangan digital hal ini sebagaimana yang dijelaskan didalam Pasal 1 ayat 12 UU ITE yakni " tanda tangan yang terdiri atas informasi elektronik yang dilekatkan, terasosiasi atau terkait dengan informasi elektronik lainnya yang digunakan sebagai alat verifikasi dan authentikasi."

Lebih lanjut, menurut Julius Indra Dwiparyo mendefinisikan tanda tangan elektronik atau digital signature adalah sebuah identitas elektronik yang berfungsi sebagai tanda persetujuan terhadap kewajiban-kewajiban yang melekat pada sebuah akta elektronik. ${ }^{14}$

Tanda tangan elektronik dalam rekam medik elektronik berupa PIN atau Password memberikan penegasan terhadap siapa pembuat rekam medik elektronik tersebut. Tanda tangan digital didalam rekam medik tersebut juga merupakan suatu cara untuk menjamin keaslian suatu rekam medik elektronik dan menjaga supaya pembuat rekam medik dalam suatu waktu tidak dapat menyangkal bahwa dirinya telah membuat rekam medik tersebut.

Adapun kerugian dan kelemahan didalam tanda tangan digital yakni:

1. Perlu adanya biaya tambahan menandatangi dokumen elektronik; Misalnya dari penyedia layanan certificate authority untuk layanan tersebut.

2. Perlunya awareness kepada user untuk menyimpan dokumen elektronik yang sudah di tanda tangani digital dalam media yang aman;

\footnotetext{
${ }^{11}$ Soerjono Soekanto \& Herkuntanto, Pengantar Hukum Kesehatan, Remadja Karya, 1987, Bandung. Halaman 146.

${ }^{12}$ Ibid Halaman 117

13 Syahrul Mahmud, Penegakan Hukum dan Perlindungan Hukum Bagi Dokter yang Diduga Melakukan Medical Malpractice, Mandar Maju, 2008, Bandung. Halaman 117.

14 Julius Indra Dwiparyo dalam Thesis Tutwuri Handayani, Pengakuan tanda tangan pada suatu dokumen elektronik didalam pembuktian hukum acara perdata di Indonesia, Universitas Diponegoro, 2009, Semarang. Halaman 47.
} 
User yang dimaksud adalah tenaga IT yang dipekerjakan secara legal dalam menyimpan dokumen asli dimedia elektronik rumah sakit/klinik yang aman agar tidak mudah untuk diretas oleh pihak yang tidak bertanggung jawab.

Sedangkan keuntungan yang didapatkan dalam menggunakan tanda tangan elektronik pada rekam medik elektronik yakni:

1. Proses mudah dan cepat;

2. Mengurangi biaya media kertas dan tinta pencetakan serta biaya untuk mengarsipkan dokumen hardcopy.

Dalam pemanfaatan rekam medik elektronik dibutuhkan sebuah perlindungan hukum bagi kerahasiaan data pasien. Mengingat system elektronik merupakan sebuah mahakarya manusia yang juga memiliki kekurangan. Perlindungan Hukum menurut Soerjono Soekanto, Perlindungan hukum adalah segala upaya pemenuhan hak dan pemberian bantuan untuk memberikan rasa aman kepada saksi dan atau korban, perlindungan hukum korban kejahatan sebagai bagian dari perlindungan masyarakat, dapat diwujudkan dalam berbagai bentuk, seperti melalui pemberian restitusi, kompensasi, pelayanan medis, dan bantuan hukum. ${ }^{15}$

Selanjutnya, menurut Philipus M. Hadjon Perlindungan Hukum adalah perlindungan akan harkat dan martabat, serta pengakuan terhadap hak-hak asasi manusia yang dimiliki oleh subjek hukum berdasarkan ketentuan hukum dari kesewenangan. ${ }^{16}$ Senada dengan hal tersebut Menurut Satjipto Raharjo mendefinisikan perlindungan hukum adalah memberikan pengayoman kepada hak asasi manusia yang dirugikan orang lain dan perlindungan tersebut diberikan kepada masyarakat agar mereka dapat menikmati semua hak-hak yang diberikan oleh hukum. ${ }^{17}$

Perlindungan hukum didalam hukum kesehatan secara umum telah di tegas didalam Undang-undang No. 44 Tahun 2009 Tentang Rumah Sakit, Undang-Undang No. 36 Tahun 2009 Tentang Kesehatan dan Undang-undang No. 29 Tahun 2004 tentang praktik kedokteran serta Peraturan menteri lainnya yang mengatur lebih lanjut tentang pelayanan medis. Namun, hal ini tidak berlaku bagi rekam medik elektronik meskipun telah diberikan keleluasaan kepada rumah sakit dalam penggunaan rekam medik elektronik sehingga setiap rumah sakit bisa mengatur sendiri-sendiri terhadap system pelayanan medis yang akan terapkan. Namun, pengaturan lebih lanjut tentang rekam medik elektronik belum mendapatkan kejelasan dan penegasan secara spesifik. Padahal seperti yang telah diketahui sebelumnya terdapat data rahasia pasien didalam rekam medik atau yang lebih dikenal dengan rahasia medis.

Rahasia medis adalah salah satu hak dari hak pasien sekaligus merupakan kewajiban sebagai tenaga kesehatan. Menurut CST. Kansil, rahasia medis adalah segala sesuatu yang diketahui oleh orang- orang seperti:

1. Tenaga kesehatan yang menurut undang - undang kesehatan;

2. Mahasiswa kedokteran, mahasiswa lain yang bertugas dalam lapangan pemeriksaan, pengobatan dan/ atau perawatan serta orang lain yang di tetapkan oleh menteri kesehatan, dan pengetahuan tersebut harus dirahasiakan oleh orang - orang di atas,

\footnotetext{
${ }^{15}$ Soerjono Soekanto, Pengantar Penelitian Hukum, UI Press, 1984, Jakarta. Halaman 133.

${ }^{16}$ Philipus M. Hadjon, Perlindungan Hukum Bagi Rakyat Indonesia, Bina Ilmu,1987, Surabaya. Halaman 1-2

${ }^{17}$ Satjipto Raharjo, Ilmu Hukum, Citra Aditya Bakti, Cetakan ke V, 2000, Bandung. Halaman 53.
} 
kecuali apabila sesuatu peraturan lain yang sederajat atau lebih tinggi daripada peraturan pemerintah yang menentukan. ${ }^{18}$

Sehubungan dengan rahasia medis terkait dengan perlindungan hukum bagi data pasien apabila terjadi konflik hukum dalam system pemeliharaan dan pelayanan kesehatan yang melibatkan dokter, rumah sakit dan pasien maka rekam medik menjadi sebuah dasar alat bukti surat yang dapat memperlihatkan bagaimana kronologi kesehatan pasien sebelum terjadinya masalah. Yang perlu dipahami adalah Rumah sakit selaku penyeleggara pelayanan kesehatan memiliki beberapa organ didalamnya yakni dokter, perawat, bagian administrasi sampai dengan cleaning service. Dalam proses pemeriksaan rumah sakit harus memiliki standar operasional dan standar pelayanan yang jelas. Standar operasional tidak hanya mengatur tentang pelayanan medis dokter, namun juga hingga pemanfaatan rekam medik (Yang dalam hal ini rekam medis elektronik) Jika dahulu rekam medis elektronik ini diarsipkan oleh tenaga administrasi berbeda dengan saat dimana rekam medis ini telah menjadi Rekam Medis Elektronik maka yang melakukan pengarsipan adalah bagian IT dari rumah sakit tersebut. Sistem informasi yang digunakan didalam rumah sakit sudah seharusnya memiliki keamanan tinggi sehingga tidak dapat diretas atau disalahgunakan oleh pihak yang tidak bertanggung jawab. Apabila dikemudian hari terjadi penyalahgunaan data pasien melalui system informasi teknologi yang digunakan oleh Rumah Sakit, maka rumah sakit turut serta dalam memberikan pertanggung jawaban kepada pasien sebagaimana doktrin vicarious liability yang berlaku didalam rumah sakit.

Secara teknis Rumah sakit juga harus menyiapkan standar operasional lain yang menjadi back up data rekam medis tersebut. Back up tersebut juga seharusnya dalam bentuk elektronik apabila memang sama sekali ingin paperless. Back up data ini seharusnya dicatatkan oleh perawat yang mendampingi dokter dengan system elektronik yang menggunakan system terpisah dengan milik dokter. Dalam arti lain pemanfaatan system informasi ini bisa seharusnya bisa dilakukan oleh dokter dan perawat dengan menggunakan perangkat yang berbeda agar dapat mengefisienkan waktu. Guna dari back up data ini adalah apabila dikemudian hari terdapat penyalahgunaan data pasien misalnya perubahan data dan kronologi kesehatan pasien oleh pihak yang tidak bertanggung jawab maka back up data lain tersebut bisa menjadi sebuah rekam medik otentik. Namun, apabila hal ini masih berat dalam hal sisi ekonomis pengunaan back up data menggunakan perangkat lain yang dapat menjadi alternative dalam menggunakan rekam medik yakni secara manual dengan menggunakan kertas.

Lebih lanjut penggunaan rekam medik elektronik sebagaimana yang telah dijelaskan diatas dapat menggunakan digital signature atau tanda tangan digital dalam pengabsahannya yang memberikan pembuktian bahwa dokter tersebutlah yang melakukan pencatatan rekam medik tersebut. Akan tetapi apabila mencermati keabsahan rekam medik sebagai alat bukti surat maka diperlukannya print out rekam medik atau rekam medik yang berbentuk fisik dan lalu di tanda tangani oleh dokter yang melakukan pemeriksaan riwayat penyakit yang bersangkutan. Namun artinya, kertas tidak dapat dipisahkan dari rekam medik mengingat fungsi kertas masih dibutuhkan.

\footnotetext{
${ }^{18}$ Hendrik, Etika \& Hukum Kesehatan, EGC, 2011, Jakarta. Halaman 11.
} 
SOEPRA Jurnal Hukum Kesehatan

ISSN:2548-818X (media online) Vol. 5 (2) Desember 2019

\section{KESIMPULAN}

Rekam medik adalah sebuah bagian terpenting dalam pelayanan kesehatan, sehingga memerlukan landasan hukum yang kuat dalam penerapannya. Dalam Undang-undang No.29 Tahun 2004 Tentang Praktik Kedokteran memberikan penegasan tentang kewajiban dalam pembuatan rekam medik sampai dengan kewajiban menjaga kerahasiaan rekam medik tersebut. Selanjutnya, secara speksifik pengaturan rekam medik diatur didalam Peraturan Menteri Kesehatan No. 269/MENKES/PER/III/2008 tentang Rekam Medik. Penjelasan rekam medik tersebut diatur secara sistematis sampai dengan memberikan kebebasan kepada rumah sakit selaku tempat pelayanan kesehatan dalam penggunaan rekam medik baik konvesional maupun elektronik yang secara sah diakui didalam PERMENKES tersebut. Akan tetapi jika dicermati lebih jauh, rekam medik yang diatur masih terbatas pada rekam medik konvensional. Pemanfaatan rekam medik elektronik hanya menjadi pengakuan saja sehingga tidak ditemukannya sebuah kepastian hukum apabila system elektronik kemudian menjadi alat bukti dipengadilan. Tidak itu saja, perlindungan hukum bagi data pasien juga belum diatur lebih lanjut, yang kemudian dalam perlndungan data pasien masih disetarakan secara konvensional.

\section{SARAN}

Berdasarkan analisis diatas maka dapat diberikan saran dalam penerapan rekam medik elektronik yakni diperlukannya sebuah Peraturan Menteri Kesehatan Republik Indonesia yang lebih jelas dan tegas terkait dengan keberadaan dan perlindungan hukum rekam medik elektronik yang memberikan penegasan terkait penerapan rekam medik elektronik disetiap rumah sakit maupun klinik. PERMEN tersebut juga harus mengatur bagaimana rekam medik elektronik apabila suatu saat dibutuhkan menjadi sebuah alat bukti didalam peradilan. Apakah harus kembali diprint out, ataukah rekam medik elektronik sudah dapat dijadikan alat bukti dengan pengabsahan dari dokter dalam bentuk password, PIN, sidik jari atau bahkan iris mata.

\section{DAFTAR PUSTAKA}

\section{Buku-Buku}

Ameln, Fred., Kapita Selekta Hukum Kedokteran, Grafikatama jaya, 1991, Jakarta.

Asyhadie, Zaeni., Aspek-Aspek Hukum Kesehatan Di Indonesia, Rajawali Pers, 2017, Depok.

Hadjon, Philipus M., Perlindungan Hukum Bagi Rakyat Indonesia, Bina Ilmu,1987, Surabaya.

Hanafiah, Yusuf. Dkk., Etika Kedokteran dan Hukum Kesehatan, Buku Kedokteran EGC, 1999, Jakarta.

Hendrik, Etika \& Hukum Kesehatan, EGC, 2011, Jakarta.

Ibrahim, Jhoni., Teori dan Metodologi Penelitian Hukum Normatif, Bayu Media Publishing, 2006, Malang.

Mahmud, Syahrul., Penegakan Hukum dan Perlindungan Hukum Bagi Dokter yang Diduga Melakukan Medical Malpractice, Mandar Maju, 2008, Bandung.

Raharjo, Satjipto., Ilmu Hukum, Citra Aditya Bakti, Cetakan ke V, 2000, Bandung.

Soekanto, Soerjono., Pengantar Penelitian Hukum, UI Press, 1984, Jakarta. 
Soekanto, Soerjono dkk., Pengantar Hukum Kesehatan, Remadja Karya, 1987, Bandung.

Soekanto, Soerjono.,Segi-segi hukum hak dan kewajiban pasien dalam kerangka hukum kesehatan, Mandar Maju, 1990, Bandung.

Supriadi, Wila C., Hukum Kedokteran, Mandar Maju, 2001.

\section{Karya IImiah}

Bagus Tri Adikarya, Artikel Ilmiah Perlindungan Hukum Bagi Dokter Melalui Reformasi Standar Pelayanan Kedokteran Berdasarkan Prinsip Kepastian Hukum, Universitas Brawijaya, 2015.

Sudjana, Aspek Hukum Rekam Medis atau Rekam Medik Elektronik Sebagai alat bukti dalam transaksi terapeutik, VEJ Volume 3 Nomor 2, Bandung, 2017.

Tutwuri Handayani, Thesis Pengakuan tanda tangan pada suatu dokumen elektronik didalam pembuktian hukum acara perdata di Indonesia, Universitas Diponegoro, 2009, Semarang.

\section{Peraturan Perundang-undangan}

Undang-undang No. 29 Tahun 2004 Tentang Praktik Kedokteran

Undang-undang No. 11 Tahun 2008 tentang Informasi dan Transaksi Elektronik

Undang-undang No. 44 Tahun 2009 Tentang Rumah Sakit

Undang-Undang No. 36 Tahun 2009 Tentang Kesehatan

Peraturan Menteri Kesehatan Nomor 749a/MENKES/ Per/XII/1989 Tentang Rekam Medik/ Medical Records

Peraturan Menteri Kesehatan No. 269/MENKES/PER/III/2008 tentang Rekam Medik

\section{Peraturan Lain}

SK PB IDI No.315/PB/A.4/88 